\title{
International Aid and Funding of Vocational Education: Lessons on Vocationalization of School Agriculture- Kenya 1959-1984
}

\author{
${ }^{1}$ Jacob J.J.Ochieng Konyango, Dip. Agric. Educ, BEd Agric. Educ, MSc.Agric.Educ, PhD, ${ }^{2}$ Daniel L.Mutisya, PhD \\ ${ }^{1}$ School of Agricultural Sciences -Machakos University, P.O.Box 136-90100, Machakos- Kenya \\ ${ }^{2}$ Kenya Agriculture and Livestock Research Organization. P.O.BOX 340 -90IO0 MACHAKOS-KENYA
}

*Corresponding Author: Jacob J.J.Ochieng Konyango, Dip. Agric. Educ, BEd Agric. Educ, MSc. Agric. Educ, PhD. School of Agricultural Sciences -Machakos University, P.O.Box 136-90100, Machakos- Kenya

\begin{abstract}
The current drive for Technical Industrial Vocational and Entrepreneurial Education (TIVET) in Kenya promising young people access to practical and vocational skills is a move to make education responsive to developmental needs of the country by promising learners a lifelong education and strategy to strengthen agricultural extension. This is despite the fact that a similar drive involving vocational agriculture between 1959 and 1984 funded by USAID, IDA and the Kenyan government remains a dream evidenced by a more theoretical curriculum lacking strategies for implementation of practical and scientific skills for school leavers. This study sought to determine why despite funding which a major factor for curriculum innovation is and implementation, practical and vocational education remains a wish and not a reality in Kenya. The target population for the study included individuals and institutions with both primary and secondary information on vocational education with reference to the funding for vocational agriculture in Kenya between 1959 and 1984. The study used qualitative research with historical design in which 26 secondary schools with an initial population of 104 respondents where vocational agriculture was taught were purposively sampled. Self-administered interview schedules, visits to schools and education offices archives for documentary sources were used to collect data. The data was synthesized and analyzed qualitatively by building an account on practical and vocational subjects' implementation. This involved selecting, organizing and analyzing the collected data in to topical themes and central ideas and concepts. The findings of this study reveal various challenges to the implementation of practical agriculture including among others emphasis on examinations. The study further shows that the subject remains an ineffective tool for relevancy in education a trend which must be addressed urgently.
\end{abstract}

Keywords: Funding, Vocational, Innovation, Implementation.

\section{INTRODUCTION}

Kenya is at it again, seeking donor funding amounting to US\$56 million sourced from the Netherlands Government and the African Development Bank in a bid to promote skills base education through vocational and technical education in which agriculture is included among other technical subjects (Ngang'a, 2010; GoK, 1976). This drive has been prompted by the existence of a worrying trend in the education system which roles out school leavers who are not only salaried unemployable nor self driven employable. This is evidenced by a perpetual stagnation and declining levels of rural development and in this aspect acts as facilitators of agricultural extension service to the farmer, this could also be a strategy to empower among others the vast army of high school leavers and university graduates and the rural farmer with skills and knowhow for gainful occupations. This is a valuable source for technical information to the farmer (Moore. \& Flowers, 2004; Fox \& Mellissa 2008).

Emerging preliminary observations to this study show that the financial support of the United States Agency for International Development (USAID), and the World Bank for the Kenya Vocational Agriculture Program between 1959-1967 (Mawell,1967; GoK,1976) did not achieve the intended purpose in line with the philosophy of (Dewey,1917). It left both the farmer and the student without a base for technical advancemet.The challenge is a scenario in which the schooling is seen as concealing within itself two opposing forces, one which utilizes the public resources to turn out laborers and professionals in line with economic status quo with assured advantages to themselves and the other which utilizes the public resources to provide an education system equipping 
individuals with skills and knowhow in controlling their future economic sustenance. This according to Bennell (2007) should be the core of vocationalization and a strategy for sustained economic development which the renewed Kenyan drive for vocationalization programme must not ignore.

Whereas the first vocational education curriculum targeting school agriculture and funded through an agreement between the Kenya Government between 1959-1974 USAID (G.O.K, 1965; Maxwell, 1965) to a tune of an amount of U.S $\$ 310,685$ had a purpose of developing of a new pattern of secondary education for Kenya emphasis in preparing the school leavers for careers in agriculture, trade, industry and community leadership. This hope and aspiration remains elusive despite the fact that the initiative was backed by the first secondary school agriculture syllabus in East Africa referred to as Agriculture Principles and Practices (EAEC, 1969).Emphasis is the curriculum should have been sustainable in order to lead to sustainable livelihoods Koulaouzides, et,al( 2003). The introduction of the 8-4-4 system of education in Kenya in 1984, which was considered to be more practical and which could have revived the aspirations of the vocational agriculture has become inconsequential due to its over emphasis in a purely academic pursuit strategy (GoK, 1984; Bennell ,2007).

Reflecting on the above scenario, the current drive may only bear fruit if a tracer study can establish the destiny of graduates of TVETI graduates in terms of job placement and career progression. This view is based on the statistics from the Government's Economic Survey showing the rise of student enrolment from 29,700 to 31,344 between the year 2008 and 2009 to Technical and Vocational Institutions (King\&Martin, 2002; GoK, 2010). The initiative raises the hopes and aspirations of both primary and secondary school students who have failed to progress for Secondary and University education respectively. However, historical analysis of vocational education in Kenya still as (FAO/ILO, 2007\&World Bank, 2014) show a disdain for vocational education, but a spirited pursuit of not only a purely academic education but also for the selection of the best in academics leading to the production of individuals who are equipped for placement in the formal sector of the economy. It can be authoritatively said that, so long as vocational education is designed to meet the needs of low achievers in public examinations the initiatives may not yield the desired objectives. This is a long time view expressed by (Nyerere, 1967; Dore, 1976 \& World Bank, 2014) comparing the desire for higher academic pursuit to a diploma disease which the current initiative of vocationalization must address.

The current strategy is according to (GoK, 2013) the strategy includes the construction of new technical institutions with a financial support of $\$ 25$ million sourced from the Netherlands Government and $\$ 31$ million from the African Development Bank to be used in buying modern equipment and training of teachers. This move is based in the belief that there is a need for 13 new polytechnics so as to increase the intake of students seeking vocational training yet many of the well equipped and leading polytechnics in Kenya have all been promoted to universities. It is worth asking whether the new polytechnics will not go the same direction of being promoted to universities where the main drive is academic papers than reaching the community in this case the farmer included.

The venture is based in the hope that for the economy to grow there is a need to invest heavily in vocational and technical education. It should however as (Kohn,1999;Maguire, 2000) points out, vocationalization require academically talented recruits who can be innovative, those who are creative and can think as they work and not mere machine handlers. A look at the 2017 Kenya Universities and Colleges Central Placing Services (KUCCPS) clearly shows that all the students who scored a C+ grade and above in the Kenya Certificate of Secondary Education qualifies for admission to a University a degree course whereas holders of a plain $\mathrm{C}$ grade downwards is destined to the dead end in vocational education at a Diploma/ a Certificate awarding College. There is no denial that both parents and their children view university education as the key to future prosperity and hence confirms the view that vocationalization is for the lower academic achievers.

\section{LiTERATURE REVIEW}

\subsection{Genesis of Funding Vocational Agriculture}

Literature revelation shows that the funding for vocational and technical education is not new in Kenya (GoK, 1965; FAO/ILO, 2007), it had been tried before with school agriculture. The funding 
was meant to empower the rural youth with vocational and technical skills and knowledge aimed at rural development, ensuring food security and improving the quality of life of the people living in rural areas. The strategy was admirable as it addressed the need of the rural youth the majority of who live in the poor; their productive capacity very low as a result of lack of skills, knowledge and resources (Sarason, 1990; UNESCO, 2012). Globally, vocational agriculture has facilitated the reduction of food shortages in a wide range of environmental challenges (GoK, 2013; U.N, 2007; Sarason, 1990). These successes despite challenges to the implantation of vocational agriculture are due to the joint efforts of scientists, agriculture teachers and extension workers who are charged with the task of disseminating new ideas to the farmers, with the aim of promoting the living conditions of the rising population. The proposed drive for vocational and technical education must not lose sight of this and should build on the ground upon which vocational agriculture stakeholders have established and beyond. Funding for vocational education has a place to play in achieving this global aspiration. For vocationalization of education to succeed ( FAO/ILO,2007; World Bank, 2014), says, it should be considered as wholesome educational encounter housing all forms of learning without ignoring the challenges of the hidden influences of white collar myth, intended or unintended and their impact on the societal development goals.

Although agriculture remains the driving engine of Kenyan economy currently contributing $24 \%$ of the GDP directly, and 27\% indirectly (Government of Kenya (GoK; 2012). Documentary sources indicates that the sector accounts for $65 \%$ of the Kenya's total exports; provides more than $18 \%$ of formal employment; accounts for more than $70 \%$ of informal employment in the rural areas and generally provides a livelihood for close to $80 \%$ of the Kenyan population. There is no evidence to link school agriculture with this performance. For vocationalization to be fully embraced, there is need to be an answer as to why there seems to be unanswered questions arising from the apparent negative attitude of students and parents to certain forms of technical and vocational education and why the high level of preference to academic education leaning to white collar job aspirations. The views expressed (UNESCO, 2012) indicates a need to reflect on our educational history, culture, aspirations and goals of action for implementation of private and national demand of certain types of education. According to (Maxwell,1965 GoK, 1976;GoK,1970), between 1959 and 1975 school agriculture enjoyed political and economic goodwill both from the international donors and local government in a desire to use school agriculture as an engine for promoting vocational skills and building scientific knowledge through problem solving. However, there appear to have been a mismatch between aspirations and the reality in which the desire for white collar job took centre stage. As (Stewart, Moore \& Flowers, 2004) points out, it is worth asking why vocational education has failed to be recognized as a venture worth pursuing by the academically gifted students, and more so, why the elaborate funding has often failed to put a mark on vocationalization. The study justifies the need for examining the vocational education funding in the past and thereafter in order to create relevancy in order to establish strategies for success in the new drive.

\subsection{The Face of Youth Unemployment}

The majority of the youths who terminate their schooling due to failure to proceed to either high school or universities seem to be reluctant to never venture into vocational education openings. This could attributed to several factors among them is attitude and aspirations of vocational school graduates. This is supported by statistical data from the Kenya National Bureau of Statistics (GoK, 2010; Ngang'a; 2010) which shows that Kenyan youth are all individuals in the Republic aged between 18 and 35 years. It is estimated that $78.31 \%$ of Kenyans are below 35 years and that $64 \%$ of unemployed persons in Kenya are youth. Only $1.5 \%$ of the unemployed youth have formal education beyond secondary school level and the remaining over $92 \%$ have been to school yet are said to have no vocational skills, according to (Stewart, Moore \& Flowers, 2004 ) reinforces the doubt on the contribution of school vocationalization in solving youth unemployment.

The drive to vocationalization in Kenya should borrow ideas as from the ( Puyate,2012), which illustrates how vocational agricultural education offered in schools provides the school leavers with core skills in agriculture which will enables them to be self reliant through self employment. This may 
only be achieved if the curriculum design takes an inclusive approach as ( King \& Martin, 2002) argues that the curriculum implementation should include sustained provision of teaching, learning resources. It should start with an assessment of needs, and specific societal problems that the curriculum designers wish to solve. In this respect, sustainability requires optimum level of returns for students and their communities.

\subsection{The Challenge to Educational Stakeholders}

Despite the apparent drive to vocationalization of the curriculum, an analysis of the views by (Bergmann, 2003; UN, 2007) indicates the need for stakeholder approach for effective implementation of the vocational education drive. The funding for the vocationalization education should reduce the drudgery of manual labor and lead to mechanization and technological advancement. This has been the base of success of vocational education in the developed countries ( King,1971; Sarason, 1990) a feature which has been ignored by stakeholders in education and economic planners in developing countries Kenya being one of them. Vision 2030 is Kenya's economic development lead flag for 2008 to 2030 which aims at making Kenya a newly industrializing "middle income country providing high quality life for all its citizens by the year 2030" ( UN,2007;GoK 2012 \& GoK, 2013) is the essence of sustainable funding for practical and vocational education. Analysis to quality education by (GoK, 1967; Lewa \&Ndung'u 2012) points out those practical and vocational oriented subjects must be given prominence in the curriculum and must be made attractive to both pupils and parents. The programmes should be designed in such a way that it plays an important role in changing the attitudes of the students in subject. Vocational subjects should be equally challenging to the recipients as other conventional subjects.

\subsection{Materials and Methodology}

This paper has investigated, examined and analyzed the funding strategy for vocationalization of education with reference to school agriculture with comparison to the current proposal of vocationalization within the context of relevancy to the societal goals and aspirations (Dewey $\&$ Dewey, 1915). The planned funding by International donors and Kenya Government is a promotion and implementation of the functionalist theories reinforced by the philosophical views of Nyerere, (1967; Haralambos \& Head, 1980) in which education is viewed as a means of helping the learners in adapting to self reliance in post school era. The success of funding for practical and technical education will according to (Brigitte,2003;Agena,2011) is evidenced in performance of those who finally go to various sections of the economy, live there and succeed, for after all, the fundamental purpose of vocational education is to ensure a productive and moving employment generating undertakings which leads to full life.

The study adopted a largely qualitative approach of historical design. It used the systematic nature of historical studies by interviews, documentation of past records from schools, education offices and archives to research for facts relating to funding of vocational and technical education. These were described, analyzed and interpreted with reference to their impact on funding in relation to curriculum reforms. The study further searched for information relating to funding for vocational and practical subjects with reference to school agriculture. The study adopted a variety of foci that historical research uses such as; issues, movements, concepts, approaches, theories and development (Smit, 2003; Wiersma, 1995). The historical research in this study contributed in covering a broad area which led to the understanding on approaches to effective implementation of vocational education. The targeted population for this study was relevant individuals and institutions with both primary and secondary sources of information on funding of vocational subjects and where they could be sourced. The study further targeted the archives, actual sites where the funded projects could be identified these included onsite visits to schools, institutes, documentary data including government plan relating to vocational education, reports and funding for vocational education agreements. The study purposively sampled 26 secondary schools in which vocational agriculture programme was funded by different agencies over the study period; the schools represented a select category of the population with specific data requirements. 
International Aid and Funding of Vocational Education: Lessons on Vocationalization of School Agriculture- Kenya 1959-1984

Table1. Vocational Agriculture Level of Funding \& utilization by Years

\begin{tabular}{|l|l|l|l|l|l|l|}
\hline $\begin{array}{l}\text { Funding } \\
\text { Source }\end{array}$ & $\begin{array}{l}\text { Year of } \\
\text { Funding }\end{array}$ & $\begin{array}{l}\text { Number } \\
\text { of } \\
\text { schools }\end{array}$ & $\begin{array}{l}\text { Agriculture } \\
\text { Workshop } \\
\text { Funds } \\
\text { Kshs. }\end{array}$ & $\begin{array}{l}\text { Tools and } \\
\text { Equipment } \\
\text { Funds } \\
\text { Kshs }\end{array}$ & $\begin{array}{l}\text { Running } \\
\text { Costs } \\
\text { Funds } \\
\text { Kshs }\end{array}$ & $\begin{array}{l}\text { Total } \\
\text { Funding } \\
\text { Kshs }\end{array}$ \\
\hline Pilot Project & $1959 / 64$ & $\mathbf{1}$ & $2,330,137.50$ & & & $2,330,137.50$ \\
\hline $\begin{array}{l}\text { USAID Funded } \\
\text { schools }\end{array}$ & 196 & $\mathbf{6}$ & $1,198,125.00$ & 43200.00 & $322,500.00$ & $12,017,820.00$ \\
\hline $\begin{array}{l}\text { IDA/World Bank } \\
\text { Funded schools }\end{array}$ & $1968 / 69$ & 20 & $8,036,325.00$ & $1,100,000.00$ & 900.000 .00 & $10,036,325.00$ \\
\hline $\begin{array}{l}\text { KenyaGovt. } \\
\text { Funded schools }\end{array}$ & $1970-74$ & $\mathbf{7 5}$ & $9,000,000$. & 75,000 & 75,000 & $9,150,000.00$ \\
\hline TOTALS & 1984 & $\mathbf{1 0 2}$ & $\mathbf{2 0 , 5 6 4 5 8 7 . 5 0}$ & $\mathbf{1 2 1 8 2 0 0 . 0 0}$ & $\mathbf{1 , 2 9 7 , 5 0 0 . 0 0}$ & $\mathbf{3 3 , 5 3 4 , 2 8 2 . 5 0}$ \\
\hline
\end{tabular}

Exchange Rates up to 1970s Kshs 7.50= US \$ 1

Current Rate Kshs 91= US \$ 1

Source: Maxwell (1966-67), GoK (1966-70\& 1970-74) Development Plans.

\section{Findings ANd CONCLUSIONS}

Evidences from documentary search sources and visits to the early vocational agriculture schools reveals a well coordinated funding (Table 1) reinforced by sound policies. The policies included establishment of home demonstration plots and school holiday farm and agricultural industry attachments for students as reinforcement for classroom activities and as community outreach strategies which is a vital linkage with farmers and the industry.

However, the findings show that since all the pioneer vocational agriculture schools were boarding, the home demonstration plots could not be implemented as this only could be implemented in Day School where students would daily interact with families and farmers after classes. Similarly, the study further reveals that there were no well planed farms to take in students for attachment.

Documentary findings further show that it was a policy for each school offering vocational agriculture to have at least 2 hectares parcel of land for not only practical farming activities but also for purposes of promoting enthusiasm and a willingness to learn by doing among students. This was also a way of relating vocation agricultural course to the entire school program; to the development of the region and the country and to the life and future of the students. The trend as at now, agriculture is taught in nearly all schools both rural and urban schools in high rise buildings.

The findings on how the funding promoted the implementation of vocation vocational agriculture paints a complete failure of vocationalization with respect to school agriculture (Table 2).

Table2. Summary Categories of Use and Status of Workshop Facilities.

\begin{tabular}{|c|c|c|c|c|}
\hline $\begin{array}{l}\text { SCHO } \\
\text { OL } \\
\text { CATE } \\
\text { GORY }\end{array}$ & $\begin{array}{l}\text { AVAILABILITY OF } \\
\text { WORKSHOP }\end{array}$ & $\begin{array}{c}\text { TOOLS / } \\
\text { EQUIPMENT }\end{array}$ & CURRENT USE & $\begin{array}{c}\text { HOW PRACTICALS } \\
\text { ARE RUN }\end{array}$ \\
\hline $\begin{array}{l}\text { PILOT } \\
\text { SCHO } \\
\text { OL }\end{array}$ & YES & $\begin{array}{l}\text { Relics and remains of } \\
\text { broken machinery, } \\
\text { other tools missing. }\end{array}$ & $\begin{array}{l}\text { Industrial } \\
\text { workshop/store/school } \\
\text { maintenance Not for } \\
\text { Agriculture }\end{array}$ & $\begin{array}{ll}\text { Teaching } & \text { Theoretical } \\
\text { Agriculture } & \\
\text { Agriculture } & \end{array}$ \\
\hline $\begin{array}{l}\text { USAID } \\
1\end{array}$ & $\begin{array}{l}\text { YES /but need } \\
\text { keenness to identify }\end{array}$ & $\begin{array}{l}\text { No tools/ equipment } \\
\text { shell of tractor wheels }\end{array}$ & Dormitory & No Workshop practicals \\
\hline $\begin{array}{l}\text { USAID } \\
2\end{array}$ & YES & $\begin{array}{l}\text { Assortment of farm } \\
\text { tools, no evidence of } \\
\text { machinery provided }\end{array}$ & $\begin{array}{l}\text { Divided in to store and } \\
\text { agriculture }\end{array}$ & $\begin{array}{l}\text { The agriculture activities } \\
\text { are Theoretical } \\
\text { Agriculture despite space } \\
\text { in workshop }\end{array}$ \\
\hline $\begin{array}{l}\text { USAID } \\
3\end{array}$ & YES & Non existence & Regular class room & $\begin{array}{l}\text { Theoretical Agriculture } \\
\text { teaching }\end{array}$ \\
\hline $\begin{array}{l}\text { USAID } \\
4\end{array}$ & YES & $\begin{array}{l}\text { Assortment of hand } \\
\text { tools no evidence of } \\
\text { machinery provided }\end{array}$ & Storage & Theoretical Agriculture \\
\hline WB 1 & YES & Shells of tractor, gas & Converted & Theoretical Agriculture \\
\hline
\end{tabular}


International Aid and Funding of Vocational Education: Lessons on Vocationalization of School Agriculture- Kenya 1959-1984

\begin{tabular}{|c|c|c|c|c|}
\hline & & $\begin{array}{l}\text { welding equipment, no } \\
\text { other tools. }\end{array}$ & laboratory & \\
\hline WB 2 & $\begin{array}{l}\text { YES/but need prior } \\
\text { knowledge to identify } \\
\text { it. }\end{array}$ & NIL & Electricity/power mechanics & Theoretical Agriculture \\
\hline WB 3 & YES & $\begin{array}{l}\text { NIL } \\
\text { Two tractors in good } \\
\text { condition but idle. } \\
\text { No other facilities }\end{array}$ & $\begin{array}{l}\text { Stores of all sorts. No room } \\
\text { for teaching area }\end{array}$ & Theoretical Agriculture \\
\hline WB 4 & YES & $\begin{array}{l}\text { Relics of drill press. } \\
\text { No other tools }\end{array}$ & Empty and lies unused & Theoretical Agriculture \\
\hline WB 5 & YES & No tools & Storage of all sorts & Theoretical Agriculture \\
\hline KG 1 & $\mathrm{NO}$ & Hoes & No Workshop & Theoretical Agriculture \\
\hline KG 2 & $\mathrm{NO}$ & Hoes & Storage & $\begin{array}{l}\text { Theoretical Agriculture } \\
\text { Agriculture }\end{array}$ \\
\hline KG 3 & $\begin{array}{l}\text { YES/but need } \\
\text { keenness to identify }\end{array}$ & $\begin{array}{l}\text { Assortment of hand } \\
\text { tools }\end{array}$ & Storage & $\begin{array}{l}\text { Practical approach part } \\
\text { of teaching }\end{array}$ \\
\hline KG 4 & $\mathrm{NO}$ & Hoes/cutlasses & No Workshop & Theoretical Agriculture \\
\hline KG 5 & YES & NIL & Power mechanics & Theoretical Agriculture \\
\hline KG 6 & YES & NIL & Regular classrooms & Theoretical Agriculture \\
\hline KG 7 & YES & Hoes/ cutlasses & Regular classes & Theoretical Agriculture \\
\hline KG 8 & YES & Assorted garden tools & Storage & Theoretical Agriculture \\
\hline KG 9 & $\mathrm{NO}$ & Hoes and cutlasses & No Workshop & Theoretical Agriculture \\
\hline KG 10 & $\mathrm{NO}$ & NIL & No Workshop & Theoretical Agriculture \\
\hline KG 11 & YES & Garden tools & Classroom & Theoretical Agriculture \\
\hline NF 1 & NO & $\begin{array}{l}\text { Workshop tools } \\
\text { assortment. } \\
\text { Gardening tools } \\
\text { Agricultural library }\end{array}$ & No Workshop & $\begin{array}{l}\text { Practicals incorporated in } \\
\text { teaching }\end{array}$ \\
\hline NF 2 & $\mathrm{NO}$ & NIL & No Workshop & Theoretical Agriculture \\
\hline NF 3 & $\mathrm{NO}$ & $\begin{array}{lr}\text { Assortment } & \text { of } \\
\text { workshop } & \text { and } \\
\text { gardening tools } & \\
\end{array}$ & No Workshop & $\begin{array}{l}\text { Practical/ Theoretical } \\
\text { Agriculture incorporated }\end{array}$ \\
\hline NF 4 & $\mathrm{NO}$ & Hoes, cutlasses & No Workshop & Practicals incorporated \\
\hline NF 5 & $\mathrm{NO}$ & Hoes, cutlasses & No Workshop & $\begin{array}{l}\text { Practical with Theoretical } \\
\text { Agriculture }\end{array}$ \\
\hline NF6 & $\begin{array}{l}\text { Multipurpose } \\
\text { workshop/ power } \\
\text { mechanics }\end{array}$ & Hoes, cutlasses & Industrial wood work & $\begin{array}{l}\text { Theoretical Agriculture/ } \\
\text { practicals } \\
\text { incorporated }\end{array}$ \\
\hline NF 7 & $\mathrm{NO}$ & NIL & No Workshop & Theoretical Agriculture \\
\hline NF 8 & $\begin{array}{l}\text { Yes clearly labeled } \\
\text { agricultural } \\
\text { workshop }\end{array}$ & $\begin{array}{l}\text { Assorted workshop } \\
\text { tools } \\
\text { Garden tools }\end{array}$ & $\begin{array}{l}\text { Regular and well organized } \\
\text { use with various teaching aids } \\
\text { Building clear }\end{array}$ & $\begin{array}{l}\text { Practical approach } \\
\text { exploited }\end{array}$ \\
\hline NF 9 & NO & NIL & No Workshop & Theoretical Agriculture \\
\hline NF 10 & $\mathrm{NO}$ & NIL & No Workshop & Theoretical Agriculture \\
\hline NF 11 & $\mathrm{NO}$ & Gardening tools & No Workshop & Theoretical Agriculture \\
\hline NF12 & $\mathrm{NO}$ & $\begin{array}{l}\text { Assorted tools and } \\
\text { equipment }\end{array}$ & No Workshop & Theoretical Agriculture \\
\hline NF 13 & $\mathrm{NO}$ & NIL & No Workshop & Theoretical Agriculture \\
\hline NF 14 & $\mathrm{NO}$ & Gardening tools & No Workshop & Theoretical Agriculture \\
\hline NF 15 & $\mathrm{NO}$ & Gardening tools & No Workshop & Theoretical Agriculture \\
\hline NF 16 & NO & Gardening tools & No Workshop & Theoretical Agriculture \\
\hline NF 17 & $\mathrm{NO}$ & Gardening tools & No Workshop & Theoretical Agriculture \\
\hline NF 18 & $\mathrm{NO}$ & NIL & No Workshop & Theoretical Agriculture \\
\hline NF 19 & $\mathrm{NO}$ & NIL & No Workshop & Theoretical Agriculture \\
\hline NF 20 & $\mathrm{NO}$ & NIL & No Workshop & Theoretical Agriculture \\
\hline NF 21 & $\mathrm{NO}$ & NIL & No Workshop & Theoretical Agriculture \\
\hline
\end{tabular}

KEY USAID - USAID PROJECT FUNDED SCHOOLS

WB - WORLD BANK /IDA FUNDED SCHOOL

KG - $\quad$ KENYA GOVERNMENT FUNDED SCHOOLS

NF $\quad-\quad$ NON-FUNDED/8.4.4 PROJECT SCHOOLS 
According to the Government Development Plan 1970/74, 75 vocational agriculture workshops were to be built and to be equipped. The study found no evidence of this having been done and where workshops had been built and equipped, the facilities were converted to other uses (Table 2).

\section{CONCLUSIONS AND RECOMMENDATIONS}

The new drive for vocationalization of education must avoid the pitfalls which undermined vocational agriculture in which the cost for the resources and facilities could not be sustained.

Proper management of resources is mandatory as there exists evidence of mis use in which vocational agriculture workshops were converted to stores, regular classrooms and dormitories.

There must be a deliberate drive to demystify that vocational education is for the low academic achievers and it must also attract bright students who can be innovators, this will require job evaluation for different category of workers and a new pattern of work remuneration which favors vocational graduates as well the purely academic employees.

There is a further need to review the trend in which placement in universities for students is a purely based on an academic and deliberately provides places for vocational education institute graduates. To consider a need to train and retrain a cadre of vocational subject teachers dedicated to the spirit of the new ideas before the reforms go into implementation.

\section{REFERENCES}

[1]. Agena, M (2011). Increasing Rural Agricultural Productivity through Technology: A story of a young Modern Fruit Grower in Apac, Northern Uganda in 'CTA ARDYIS Essay content; 2011.

[2]. Bennell, P. (2007).' Promoting Livelihoods Opportunities for Rural Youth 'International Fund for Agricultural Development.

[3]. Bergmann. H. (2003). Practical Subjects in Basic Education- Relevance at Last or Second Rate Education? Lessons from 40 Years of Experience. GTZ Eschborn

[4]. Brigitte, S (2003, June). Can Qualitative Research Inform Policy Implementation?

[5]. Dewey, J. and Dewey, E. (1915). Schools of To-morrow. New York: E.P. Dutton and Company

[6]. East African Examinations Council. (1969). Agriculture Syllabus and Regulations. Kampala, EAEC

[7]. FAO/ILO/ Ministry of Agriculture. (2007)."Comparative Study of the Job-Creating

[8]. Capacity and Efficiency of Crops and Related Activities in Liberia" Report submitted by ITTAS Consultancy Ltd, Accra, Ghana. .

[9]. Government of Kenya, (1965). The Kenya Education Commission. Nairobi: Government Printers.

[10]. Government of Kenya. (1970).Development plan. Nairobi: Government Printers

[11]. Government of Kenya, (1976). The Report of the National Committee on Educational Objectives and Policies. Nairobi: Government Printers.

[12]. GOK (2010): Ministry of State for Planning, National Development and Vision 2030: Kenya Population and Housing Census, 2009. Kenya National Bureau of Statistics: Nairobi; Government Printers

[13]. Government of Kenya, (2012). National Agricultural Sector Extension Policy: Republic of Kenya (NASEP). Nairobi, Government Printer

[14]. Government of Kenya (2013). Ministry of Devolution and Planning Second Medium Term Plan, 2013 2017; Vision 2030: Transforming Kenya: Pathway to Devolution, Socio-Economic Development, Equity and National Unity. Nairobi. Government Printer

[15]. Haralambos, M and Martin, H. (2013). Sociology: Themes and Perspectives. Slough: University Tutorial Press.

[16]. King, K. \& Martin, C. (2002). The Vocational school Fallacy Revisited: education, Aspirations and Work in Ghana 1959-2000. International Journal of Educational Development. 22, (2002) 5-26.

[17]. King, K.J. (1971). The Politics of agricultural education for Africans in Kenya. In B.A. Ogot (Eds) Proceedings of the 1969/70 3rd Conference of the Historical Association Nairobi, Hadith 3.East African Publishing House

[18]. Kohn, A. (1999). The Schools Our Children Deserve: Moving Beyond Traditional Classrooms and 'Tougher Standards'. Boston: Houghton Mifflin Co.

[19]. Koulaouzides, G.A., E Vergos, D.G. Acker, and Crunkilton, J.R, (2003) "Promoting Sustainability in the Balkan Region of South-Eastern Europe through Innovative Curriculum Practices in Agricultural Education.”Journal of International Agricultural and Extension Education, Vol. 10, No. 1, Spring 2003 
[20]. Lewa, K.K. and Ndung'u J.M. (2012). Does educational level influence the choice of farming as a livelihood career? Results of an empirical study from coastal lowland Kenya. Retrieved 0n 3/3/2014 from www.futureagriculture

[21]. Maguire, J.C. (2000). Agricultural Education in Africa: Managing change. Paper Prepared for Workshop 2000 Sasakawa African Association. Accra and Cape Coast Ghana

[22]. Maxwell, R.H. (1967). Progress Report AID/afr- 298 West Virginia university USAID Project Kenya Vocational Agriculture Education July-Dec 1967. Morgan Town: West Virginia

[23]. Ngang'a, G. (2010) Kenya: Major plan to improve training institutions University

[24]. World News 2007-2014 July 2010 Issue No: 58

[25]. Nyerere, J. K. (1967). Education for Self-reliance. Dar es Salaam: Tanzania Government

[26]. Puyate, S. T., (2012). Constraints to the Effective Implementation of Vocational

[27]. Education Program in Private Secondary Schools in Port Harcourt Local Government area. Asian- Pacific Journal of Co-operative Education 9 (1): 59-71.

[28]. Sarason, S.B. (1990). The Predictable Failure of Educational Reform: Can We Change Course Before It's Too Late? San Francisco: Josey-Bass, Inc

[29]. Smit, Brigitte. (2003, June). Can Qualitative Research Inform Policy Implementation? Evidence and Arguments from a Developing Country Context. (29 Paragraphs) Forum Qualitative Research 4 (3) Article 6.

[30]. Stewart, R.M. Moore, G.E. \& Flowers J. (2004) Emerging Educational and Agricultural

[31]. Trends and Impact on the Secondary Agricultural Education Program. In journal of Vocational Education Research. 29(1), North Carolina State University

[32]. UNESCO. (2012). Youth and Skills: Putting education to work. Paris: UNESCO

[33]. United Nations. (2007). "World Youth Report 2007” Young Peoples Transition to Adulthood: Progress and Challenges. New York

[34]. Vaughn, R. (1999). Do We Still need Agricultural Education .The Agricultural Education Magazine(Jan/Feb 1999, Vol. 71 (4), pp. 4-5).

[35]. World Bank. (2014). Governance in Secondary Education: Managing Expansion and Quality Improvement in Expanding Opportunities and Building Competencies for Young People: A New Agenda for Secondary Education The World Bank: Washington

Citation: J.J.J. Ochieng Konyango," International Aid and Funding of Vocational Education: Lessons on Vocationalization of School Agriculture- Kenya 1959 -1984. ", International Journal of Research Studies in Agricultural Sciences, vol. 3, no. 11, p. 57-64, 2017. http://dx.doi.org/10.20431/2454-6224.0311005

Copyright: (C) 2017 Authors. This is an open-access article distributed under the terms of the Creative Commons Attribution License, which permits unrestricted use, distribution, and reproduction in any medium, provided the original author and source are credited. 